\title{
China's Strategic Growth Sustainment: Accidental Leader?
}

\author{
Zdzislaw Sliwa ${ }^{*}$
}

One country survived the recent economic turmoil and became stronger economically. China's economy kept growing and her GDP in 2009 reached 8,7\% despite the crisis. ${ }^{1}$ The role of China in the world economy was clearly visible in 2009 not only because of her economic growth. In April 2009 Chinese importance in the world was underlined during the G-20 Summit in London as the first face-to-face meeting between Presidents Barrack Obama and Hu Jintao was the most important event of the summit. Mr. Obama said that

bilateral relations between the countries have become extremely constructive, ... and strong ties are not only important for citizens in both countries but also help to set the stage for how the world deals with new challenges. ${ }^{2}$

During the Copenhagen Climate Summit of December 2009, China demonstrated its political might further by attempting to steer the Summit without American involvement, which simultaneously suggests just how China planned to deal with those new challenges. Although China avoided the charge of trying to usurp America's place as global hegemon, the incident reveals the depth of ambition of the new regional power. This paper will try to gauge its depth of capability.

Natural resources fuel this ambition and this capability. The country is still building its image and is considered to be second economy of the world at the dawn of the second decade of the 21 st century. The way China handled the recent crisis was monitored with great care, the courageous precautionary measures connected with investing money in internal market and creating new employment possibilities attracted particular attention. On the other hand, the recent global crisis is still the biggest threat to China's economy as she highly depends on foreign trade and investment, so economic problems of her major trading partners have a strong impact on the country. As the situation is stabilizing, the country is facing future economic challenges such as an inflexible currency policy, state-owned enterprises, a centrally controlled banking system, public unrest, governance problems and growing pollution. ${ }^{3}$ The next issue facing Chinese economy is energy hunger. Before 1993 China was self-sufficient regarding

* Colonel Zdzislaw Sliwa, PhD is a member of the Polish Armed Forces, seconded as a faculty advisor at the Baltic Defence College. The author is solely responsible for the views expressed here. They in no way reflect the policies of any government.

1 "China GDP grows by 8.7 percent in 2009," CNN China (Beijing, 20 January 2010); available at www.cnn.com/2010/BUSINESS/01/20/china.GDP.annual/index.html.

2 Hu Jintao, "Obama agrees to build positive Sino-US ties," CCTV (Beijing, 2 April 2009); available at www.china.org.cn/video/2009-04/02/content_17540900_2.htm.

3 Wayne M. Morrison, "China's Economic Conditions," CRS Report for Congress (Washington, DC: Congressional Research Service, 20 November 2009), 15-17; available at http://opencrs.com/document/RL33534/2008-11-20. 
oil and in just ten years she became the second consumer of oil in the world and the third importer. "From 2000 to 2005, China's energy consumption rose by 60 percent, accounting for almost half of the growth in world energy consumption." 4

Energy demands have caused Chinese foreign policy to become synonymous with energy security issues, and emerged as a critical aspect of the country's development influencing spheres of economy and policy. Such an attitude is especially visible in the case of Africa, as long term approach, based on the fact that some $33 \%$ of total oil imports come from that continent. China is investing huge sums of money to support selected countries and their infrastructure, medical facilities and schools but also selling weapons. In its own way, China could achieve in the Third World what the First World never could - lasting stability and development. As a consequence, China could become most-favored importer of African goods, denying an important source of cheap labour and resources to the North.

China is treating diversification of sources as important factor, and is considering very seriously how to handle any possible disruption of oil supplies in the future. In the past, China needed to be merely assured of the adequacy of energy supplies. Now however, concerns have arisen about the vulnerability of trade routes which link it to the Middle East and exposed sea lines of communications (SLOCs). The situation caused China to try finding new suppliers and to tighten relations with old ones. Quite naturally she started to look closer at neighboring countries as they have common interests, similar security concerns, leadership type and common borders. The paper will focus on Chinese energy related relations with Russia and Central Asia. It will mainly discuss economic ties and their possible development. Next, common (military) efforts to preserve safe and secure environment will be considered as critical aspect to ensure undisrupted flow of oil and gas. The Shanghai Cooperation Organization (SCO $)^{5}$ internal cooperation will be examined as facilitator of such a mutual approach to asymmetrical threats to energy security for the whole region. Finally, vulnerability of sea lines of communications will be presented and ways to minimize the influence of their disruption by extending existing and building new land pipelines reaching China. Underlying this analysis is the hypothesis that these developments are the product of a double strategy of containment, and not only in response to asymmetrical threats. The political pressures levelled by the West against Russia due to high-handedness in the Caucasus are one level of containment. The other is applied by the West to China as it conditions further cooperation with improvements of human rights and environmental sustainability. These pressures have the consequence of driving these two giants into each other's arms. At a certain level, this paper cautions policy-makers from the West not to make too harsh demands on each government, lest they become allies more formally than the SCO will allow.

4 Surya N. Yadav, India, China and Africa. New Partnership in Energy Security (New Delhi: Jnanada Prakashan (P\&D), 2008), 21.

5 The SCO members are: China, Russia, Kazakhstan, Kyrgyzstan, Tajikistan and Uzbekistan. Moreover, the treaty observers are: Mongolia, Pakistan, India and Iran. Belarus has also applied for an observer status. 


\section{Old and New Friends}

Undisturbed access to energy has become essential part of every modern economy and a source of competition among the most powerful countries. So possible "political instability of several energy producing countries, the manipulation of energy supplies, the competition over energy sources, attacks on supply infrastructure, as well as accidents or natural disasters" 6 are a real challenge to China. This is critical as only continuous access to energy can sustain the growth of the Chinese economy, which is directly helping to lift citizens out of poverty, especially in less developed parts of the country. At the same time the unbroken pace of development is important for government to keep control of the population as expectations rise higher than ever; people want to benefit from a better economical situation, so energy security is a critical political topic. In 2005 China consumed about 6.9 million barrels per day (mbd) of oil and in 2025 is projected to use $13.2 \mathrm{mbd}$. As only $4.0 \mathrm{mbd}$ will be produced in China itself, the rest will be imported, which is very significant number reaching about $9.2 \mathrm{mbd}^{7}$ To cover such demands China is considering different sources of energy resources including Russia, Central Asia, Canada, South Africa, Middle East and some African nations. This diversification of sources is driven by the means of transportation. It is important for China to diversify the ways in which she is receiving energy. At the same time the country is trying to create supportive climate and security conditions in those areas to assure the uninterrupted flow of supplies over a long period.

The long term cooperation with Russia is important for China because Russia has the largest natural gas fields in the world and ranks eighth in oil reserves. Further, Russia controls important pipelines in the region and in Central Asia. At the same time Russia is influencing Europe's energy security by controlling the pipelines to the European Union. Next, investing money in Russia's outdated oil infrastructure increases economic and political influence. Nevertheless, Russia remains an important player ranking 9th in the economies of the world. However, at present there are significant restrictions regarding funds to invest; even if China has big surplus, it will invest only when bilateral profits will be felt. The Sino-Russian partnership emerged in 2001 when Presidents Jiang Zemin and Vladimir Putin signed a Treaty of Alliance, which settled the main border disputes to improve bilateral relations, so the preconditions to work closer have been established. ${ }^{8}$ The resource issue was also part of the discussions between the Chinese and Russian governments in September 2004. During the meeting "the Chinese Prime Minister Wen Jiabao offered Russia 12 billion US \$ as financial loans and grants to expedite development of the enormous petroleum reserves in east-

\footnotetext{
Yadav, India, China and Africa, 3.

Ibid., 22.

8 C. Fred Bergsten, Bates Gill, Nicholas R. Lardy, and Derek Mitchell, China: The Balance Sheet: What the World Needs to Know About the Emerging Superpower, Center for Strategic and International Studies and Institute for Internationa Economics (New York: Public Affairs, 2007), 121.
} 
ern Siberia." ${ }^{9}$ Both countries are involved in trade cooperation in Central Asia, which is mainly focused on raw materials but

if a system of gas and oil pipelines to provide energy to China from Central Asia is constructed, bringing to an end Russia's monopoly over the transit of Central Asia energy, the balance in Central Asia trade will shift sharply in China's favour. ${ }^{10}$

That can cause some disturbances between Russia and China over influence in the region. Such a possibility cannot be excluded in the long term and could influence the bilateral relations and the cohesion of the SCO. So far in our analysis, however, the objective conditions of the global strategic environment and the nature of the SCO point to greater cohesion in the future.

The next Asian region that is strategically important for China is Central Asia. As they are sharing borders, the direct land link is again a significant advantage. Moreover, this is an opportunity to provide the shortest land link to Iran, Iraq and the whole Middle East, so that could be long-term incentive to continue good relations based on economic cooperation. For example, in 2004 the Chinese National Petroleum Company (CNPC) started a project to connect China with the Middle East by building a new pipeline. Next to economy, China is also cooperating with Kazakhstan, Kyrgyzstan, Tajikistan and Uzbekistan in the frame of the Shanghai Cooperation Organization. The economic ties are developing as one side can offer huge reserves of oil and gas, and the other is ready to buy almost unrestricted quantities of them. Kazakhstan is more and more an important oil and gas producer in the world as it plans to produce $3.5 \mathrm{mbd}$ of oil and $60-80$ billion cubic meters $(\mathrm{bcm})$ of associated gas by $2015 .{ }^{11}$ The country is also looking for diversification of clients and routes of transport to avoid any country pressuring her economically. Sino-Kazakh cooperation began in 1997 and is developing very quickly and the Kazakhstan-China Crude Oil Pipeline was a significant step ahead, as their 2008 bilateral trade reached 17.55 billions USD. As CNPC bought PetroKazakhstan in August 2005-making its largest acquisition abroad-the situation changed for the better. Such steps will serve further the partnership between all Central Asian countries, as well as between Russia and China, whose closeness will go beyond energy interests "through well-elaborated projects like Aktobemunaigas, PetroKazakhstan, and the Kazakhstan-China pipeline."12 Chinese cooperation with

9 Major M.J. Barry, “China Will Not Be a Superpower," Course New Horizons Paper (Toronto: Canadian Forces Command and Staff College, 19 April 2006), 6.

10 Vladimir Paramanov and Alexey Strokov, "Economic Involvement of Russia and China in Central Asia" (Swindon: Conflict Studies Research Centre, Defense Academy of UK, May 2007), 9-10.

11 Mehmet Ögütçü, “Kazakhstan's Expanding Cross-Border Gas Links. Implications for Europe, Russia, China and Other CIS Countries," Volume 17 (Dundee, UK: The Centre for Energy, Petroleum and Mineral Law and Policy at the University of Dundee, 2008), 1; available at www.dundee.ac.uk/cepmlp/journal/html/Vol17/Vol17_8.pdf.

12 Zhanibek Saurbek, "Kazakh-Chinese Energy Relations: Economic Pragmatism or Political Cooperation?" The China and Eurasia Forum Quarterly 6:1 (Washington, DC: Central AsiaCaucasus Institute and Silk Road Studies Program, February 2008), 93. 
Uzbekistan has also been developing, especially after the 2005 tragedy in Andijan, Uzbekistan which she treated as a terrorist attack. ${ }^{13}$ From 2006, CNPC has been involved in an international consortium which comprises state-run Uzbekneftegaz, LUKoil, Petronas, and Korea National Oil Corporation aiming to exploit oil and gas fields located in the bed of the Aral Sea. China is still very involved in supporting the country and the whole region to preserve safe and secure environment, which is critical to continue economic teamwork, as it is essential for development continuity. What we are seeing here are SCO members defining their cooperation through energy resource exploitation. In some ways, this mirrors the development of the European Union fifty years ago. The EU has been purposefully created to avoid violent conflict in Europe by placing strategic resources (coal and steel, and then nuclear energy) into a common market. China, Russia and Central Asia are leveraging the SCO to achieve the same ends with oil and gas. This has the hopeful prospect of peaceful integration on the one hand which could lead to ever-deepening political ties, but it could also turn into a super-conglomerate which acts as a counterweight to a political European and Euro-Atlantic partnership.

Although Turkmenistan is not a SCO member, the country is observing the cooperation quite closely, and is continuing trade relations with all countries of the Organization. From the Chinese point of view, this country is a good partner in the energy sector because of resources and land connections. Turkmenistan has the fourth largest reserves of gas in the world, with gas being the most important sector of the national economy. It is mainly transferred to clients via Russian Gazprom, and as the struggle over gas prices in 2006 proved, Turkmenistan is not necessarily happy with the current cooperation. So the project of a Turkmenistan-China gas pipeline is rather interesting. Moreover, China is the partner who is focusing the most on economic cooperation and, compared to the West (the US in particular), it does not condition investment to democratic and economic reform. Diversification of supplies and routes is really beneficial for both countries and is meeting their expectations especially as current issues are also forcing to look for new partners as Russia's Gazprom stopped supplies from Turkmenistan in April 2009, when a pipeline explosion created losses in Turkmenistan economy which reached about $\$ 1$ billion a month in revenues, and the countries "were blaming each other as to the causes of the accident." 14

The occasional conflict over gas and oil deliveries puts a dent in the theory that the political containment of Russia on the one hand and the economic containment of China on the other are creating a new trading block. Yet, the concept of an "SCO Energy Club" was raised during the SCO summit on 15 June 2006 by the President of the

13 The Andijan massacre took place on 13 May 2005 when security forces shot into a crowd of protesters. The West condemned Uzbekistan but the Shanghai Cooperation Organization characterized the uprising as a terrorist plot. See "How the Andijan Killings Unfolded," $B B C$ News (17 May 2005); available at http://news.bbc.co.uk/2/hi/4550845.stm.

14 Jayesh Vasava, "China Frees Turkmenistan from the Diktats of Gazprom," The Article Alley (13 February 2010); available at www.articlealley.com/article_1395438_19.html. 
Russian Federation to coordinate generation, trade, and consumption strategies of SCO member states

for the long-run through attainment of a broad consensus among representatives from government authorities, business communities, and scholars in the states engaged in generation, consumption and transit of hydrocarbon resources. ${ }^{15}$

Supported by other nations, the Draft Energy Club provisions were presented in Moscow on 19 June 2007 during a meeting attended by experts from the fuel and power sector of SCO member states. However, only five states supported the resolution about the establishment of an Energy Club: China, Kazakhstan, Kyrgyzstan, Russia, and Tajikistan. Uzbekistan had a separate point of view, but probably will join later. The issue was under discussion during the SCO summit held in Bishkek in August 2007, when Kazakhstan saw the Energy Club as part of a pan-Asian energy strategy initiative.

The Energy Club issue was again raised by Russian Prime Minister Vladimir Putin during the SCO forum in Beijing on 14 October 2009. He underlined that

Energy traditionally holds a key position on the global agenda, which prompts me to remind you of Russia's proposal to set up a permanent mechanism for dialogue on the issue, a SCO energy club or forum. ${ }^{16}$

The proposition is still under consideration to enhance economic cooperation of member states by bilateral and multilateral talks. Formal activation of such a forum would be good for China as in the long-term it would serve her energy security needs and would make closer cooperation with SCO members easier to face different threats. SCO observer countries are also important in the equation. India, Iran, Mongolia and Pakistan were present during the meeting. Iran is especially important as a possible partner of the Energy Club because of her vast quantities of raw materials to fill up the pipelines of the project, and her stake in a nuclear future which is contentious in the region.

Looking for enhancing cooperation with the Middle East, China looks closely to Central Asia, as the prospect of boosting oil and gas flow from Iran, Iraq and Saudi Arabia are rather promising. Additional direct lines of supplies are attractive. Iraq is in a peculiar situation now because of Executive Order 12959 "Prohibiting Certain Transactions with Respect to Iran" which was renewed by Notice of 11 March 2009 which is prolonging by one year the national emergency with respect to Iran. ${ }^{17}$ Such a document is putting an embargo on US companies and is giving, to an extent, more options for China. As Iran has about 125.8 bln barrels of petroleum, with capacity to

15 Energy Club of Shanghai Cooperation Organization (SCO), Russian Prime Minister Website, 29 October 2008, www.premier.gov.ru/eng/visits/world/6079/info/2281.

16 "Putin Pushes SCO Countries to Form Energy Forum," RIA Novosti (14 October 2010); available at http://en.rian.ru/russia/20091014/156460382.html.

17 Continuation of the National Emergency with Respect to Iran, Presidential Documents, Notice of 11 March 2009; available at http://regulations.justia.com/view/137983. 
raise output from $4 \mathrm{mbd}$ to $7 \mathrm{mbd}$, China can use them to start lucrative pipeline projects by connecting with the Central Asian and Chinese systems. ${ }^{18}$ The recent project of SINOPEC to buy 250 million tons of liquefied natural gas over 30 years is another promising signal. ${ }^{19}$ Similarly China's trade cooperation with Saudi Arabia, which is largest crude oil provider, in a few years will bring the bilateral trade volume up to 40 billion USD. If Iraq's Rumaila Oil Field is added, which is about $15 \%$ of Iraq's oil reserves and contains 17 billion barrels, the land concerns are really important for China, particularly as British Petroleum and CNPC signed an agreement worth 50 billion USD on 2 November 2009 to develop that field. ${ }^{20}$

\section{Shaping the Environment}

China's internal security is dependent upon its continued economic growth. That growth depends on oil and gas imports. As was said earlier, it is no longer sufficient that this flow of resources be adequate. The vulnerability of trade routes in what remains a rather difficult region must be addressed, and that means deploying political and military means of securing the undisturbed flow of resources. The SCO, created in 2001 with Russia and China as leading powers and the Central Asia countries as members, has emerged as the preferred coordination forum for such a task, and represents a quantum leap in regional political and perhaps military integration. The main goals of the organization are supporting common cooperation to improve mutual trust and good-neighbourly relations, to promote the consolidation of peace and stability in the region, but also to jointly act against the so-called "three evils" of terrorism, separatism, and extremism, while working together to foster regional cooperation in the economic, political and defense spheres. ${ }^{21}$

Such goals have been implemented by different means, especially through bilateral and multilateral exercises which are supporting member states, and sending a kind of a proclamation to the international community that "there is no 'vacuum' in Central Asia's strategic space" to be occupied by security organizations from outside the region. ${ }^{22}$ Evidently, the coercive nature of that statement is best represented by a credible military posture.

18 Cindy Hurst, China's Global Quest for Energy (Washington: The Institute for the Analysis of Global Security, January 2007), 7; available at www.iags.org/chinasquest0107.pdf.

19 Yadav, India, China and Africa. op. cit., 26.

20 "Iraq Seals Oil Deal with BP, CNPC," China Daily (4 November 2009); available at http://english.peopledaily.com.cn/90001/90777/90854/6802735.html.

21 Charter of the Shanghai Cooperation Organization, Article 1 "Goals and Tasks," SCO Website, www.sectsco.org/EN/show.asp?id=69. See also "Three Evils: Terrorism, Separatism and Extremism," SCO Joint Statement (Shanghai Convention on Combating Terrorism, Separatism and Extremism, October 2001); SCO Website: www.sectsco.org.

M.K. Bhadrakumar, "Shanghai Cooperation Organization Primed and Ready to Fire: Toward a Regional and Global Realignment?" Japan Focus (10 August 2007), revised from an article in Asia Times on 04 August 2007; available at http://japanfocus.org/products/details/2494. 


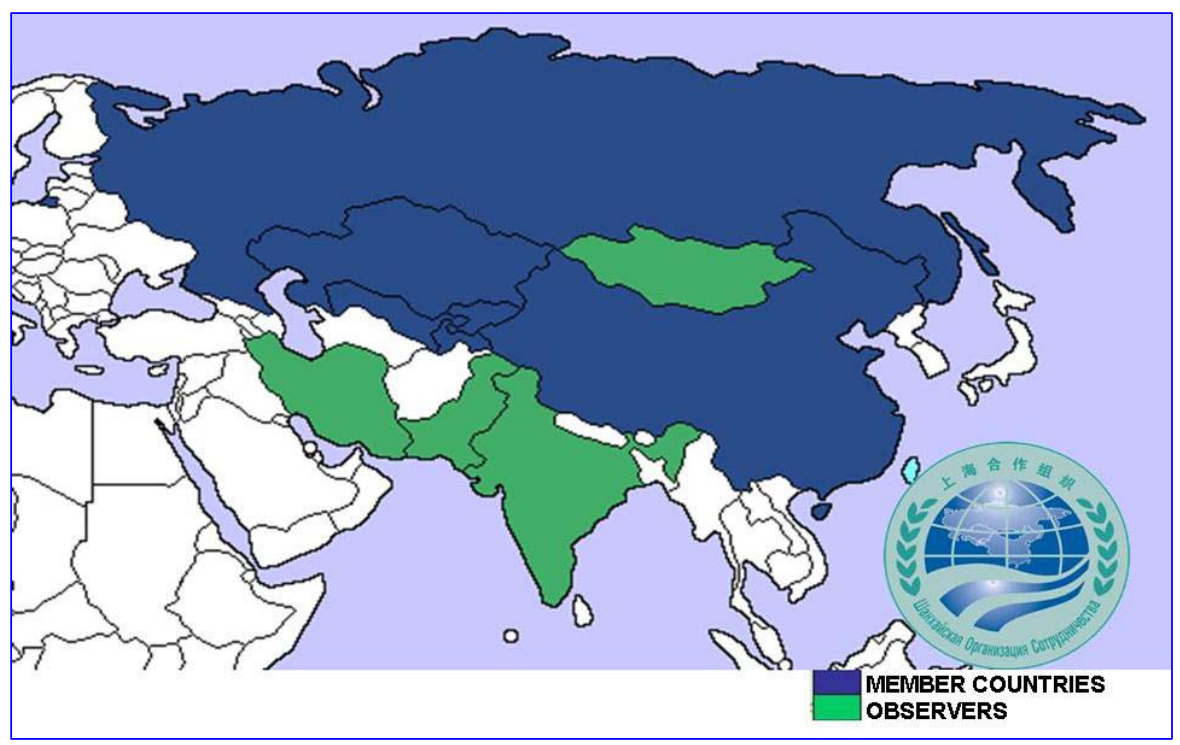

Figure 1: Shanghai Cooperation Organization.

(Source: http://encyclopedia.thefreedictionary.com)

The first military exercise took place in 2002 when China and Kyrgyzstan conducted a bilateral antiterrorist exercise "Exercise-01" from 11 to 12 October in their border areas targeting terrorism as a regional threat. ${ }^{23}$ Military cooperation was continued in 2003 during the anti-terror military exercise "Coalition-2003" (6-12 August 2003) in eastern Kazakhstan and in the Ili area of the Xinjiang Uygur Autonomous Region. It was the first multilateral joint anti-terror drill with the participation of armed forces from China, Kazakhstan, Kyrgyzstan, Russia and Tajikistan ${ }^{24}$ with some 1300 troops. Following the scenario, SCO joint forces encircled and annihilated the terrorists using special anti-terrorism equipment, information technology, helicopters, tanks, infantry combat vehicles and self-propelled artillery. After the exercise, Major General Cheng Bing, commanding the Chinese troops during exercise, stated that the "Joint Anti-terrorism exercise of the SCO Member Countries,..., was a great success and achieved anticipated results." 25 A similar bilateral exercise between the Chinese and Tajik troops, "Cooperation-2006" (22-23 September 2006) also focused on interna-

23 "Major PLA-Related Joint Anti-Terror Military Trainings," News Agency Xinhua, PLA Daily (22 December 2007); available at http://news.xinhuanet.com/english/2007-12/21/content 7290327.htm.

24 Liang Yongli and Du Xianzhou, "Coalition-2003: A Successful Joint Anti-terrorism Maneuver,” PLA Daily (14 August 2003); available at http://english.pladaily.com.cn/special/5army/ txt/61.htm.

25 Ibid. 
tional terrorism, dealing with crises, and strengthening each country's capacity to handle new challenges and threats.

The most important exercises were codenamed "Peace Mission" and they have been conducted so far every second year. A Chinese-Russian joint military exercise "Peace Mission 2005," held from 18-26 August 2005 in Vladivostok (18-19 August), in China's Shandong Province in Qingdao (20-22 August) and the third phase from 23-26 August using the Yellow Sea area included long-range bomber flights and cruise-missile drills. ${ }^{26}$ The military maneuvers involved some 10,000 military personnel from all services.

The main purpose of the drill was the improvement of cooperation between the two armies and establishing proper coordination in combating "international terrorism, extremism and separatism" and "to handle crises and meet new challenges and threats.", To show regional and security focus then chiefs of the General Staff of the People's Liberation Army General Liang Guanglie and of Russian Federation General Yuri Baluyevsky underlined that "This exercise does not target, concern the interests of, or pose a threat to any third country" and "has no intent to build a military bloc by the two giants. ${ }^{28}$ But the amphibious vehicles, missile destroyers, submarines, Tu-22M3 and Tu-95 strategic bombers and A-50 early warning aircraft suggested that it was a kind of test for multinational cooperation and coordination of modern military maneuvers to face larger scale, conventional military operations. ${ }^{29}$ Next in the sequence, the exercise "Peace Mission 2007" was held in Urumqi, the capital of China's Xinjiang Uyghur Autonomous Region and in Chelyabinsk in Russia's Volga-Ural military district from 9-17 August "to demonstrate the determination of the SCO member states in the fight against the three evils, as well as the common desire to ensure security and stability in the region and stimulate common development and prosperity." ${ }^{30}$ The goals were supported by the Heads of state from all the member countries of the SCO, who observed the final phase just after they had closed the SCO Summit in Bishkek on 16 August $2007,{ }^{31}$ demonstrating a dedication to combat the three evils of terrorism, separatism

26 Sun Shangwu and Wu Zhiyi, "First Joint Drill with Russia Launched," China Daily (19 August 2005); available at www.chinadaily.com.cn/english/doc/2005-08/19/content_470355_ 2.htm.

27 "China, Russia to Launch Military Drill," China Daily (2 August 2005); available at www.chinadaily.com.cn/english/doc/2005-08/02/content_465587.htm.

28 Shangwu and Zhiyi, "First Joint Drill with Russia Launched."

29 Erica Marat, "Fissures in the Force - Multilateral Co-operation Can Only Go So Far," Jane's Intelligence Review (01 June 2007), 4; available at www.silkroadstudies.org/new/docs/ publications/2007/Marat0507.pdf.

30 Marcel de Haas, "The "Peace Mission 2007" Exercises: The Shanghai Cooperation Organization Advances," Central Asian Series 07/28 (Shrivenham: Advanced Research and Assessment Group, UK Defence Academy, September 2007), 2; available at www.clingendael.n1/publications/2007/20070900_cscp_paper_haas.pdf.

31 The text of the Bishkek Declaration is available on SCO Wébsite www.sectsco.org and on the summit site www.scosummit2007.org. 
and extremism, recognized as the real threat to peace and stability in the region. ${ }^{32}$ What is important is that all the SCO members, for the first time, participated in such an exercise sending a total of 6,500 troops including: 4,700 from Russia (2,000 exercising units and 2,700 exercise support units), 1,600 from China, two paratrooper companies (of about 100 men each) from Tajikistan and Kazakhstan, a platoon from Kyrgyzstan and 15 staff officers from Uzbekistan. ${ }^{33}$ "Peace Mission 2007" was less ambitious (no tanks and strategic bombers) and less offensive than "Peace Mission 2005," but internal security personnel was involved in the framework of 46 episodes (e.g. Border Guard Troops, the Interior Ministry's Internal Troops and special police - OMON). The change of posture from heavy to light was expressed by the Deputy Commander of the Russian Airborne Forces general Vladimir Moltenskoi, who stated that it was a typical antiterrorist exercise, where tanks, submarines and bombers did not have a place. ${ }^{34}$ Such an event showcased

the improved security cooperation among the SCO member states, the reinforced antiterror capability of SCO members, the improved Sino-Russian relationship and the modernization of the member countries' armed forces. ${ }^{35}$

The bilateral exercise "Peace Mission 2009" demonstrated continuity and was held from 22 to 26 July 2009 in Russia (Khabarovsk) and in China's Jilin province. For the exercise both China and Russia involved 1300 troops from land and air forces, supported by about 300 pieces of land equipment and over 60 fixed-wing and rotary aircraft. The degree of ambition was still lower than two years before, and it is not impossible that the economic downturn may have been a cause of this lower ambition level in 2009.

"Peace Mission 2009" was based on antiterrorist scenarios to show both countries' capabilities to deal with such threats and to show other SCO members again that they are ready to support them actively when it would be necessary to face "the three devils." According to General Chen Bingde "it had more political than military importance" and the concept will be continued "with Russia and in the frame of the SCO.",

32 "Hu's Visit to C. Asia, Russia Fruitful," China Daily (29 August 2007); available at www.chinadaily.com.cn/china/2007-08/19/content_6033061.htm.

33 Le Tian, "Joint Drill Enters the Final Phase," China Daily (17 August 2007), 2; available at http://www2.chinadaily.com.cn/china/2007-08/17/content_6030570.htm.

34 Viktor Litovkin, "Chinese Army Trains on Russian Territory," Nezavisimoe Voennoe Obozrenie 25 (03 August 2007), 3; available at www.arba.ru/news/2588.

35 Bhadrakumar, "Shanghai Cooperation Organization Primed and Ready to Fire."

36 "Joint exercise Peace Mission 2009 between the RF and the PRC is more of a political than military importance - Chief of the General Staff," Land Force News (24 July 2009); available at www.mil.ru/info/1069/details/index.shtml?id=65211. 
Table 1: Forces Participating in Military Exercises "Peace Mission.,"37

\begin{tabular}{|c|c|c|c|c|}
\hline Codename & Date & Location & Participants & Troops \\
\hline $\begin{array}{l}\text { Peace } \\
\text { Mission } \\
2005\end{array}$ & $\begin{array}{l}18-26 \\
\text { August } \\
2005\end{array}$ & $\begin{array}{l}\text { Vladivostok, Russia; } \\
\text { Shandong province, } \\
\text { China; Yellow Sea }\end{array}$ & China, Russia & $\begin{array}{c}10000 \\
\text { soldiers }\end{array}$ \\
\hline $\begin{array}{l}\text { Peace } \\
\text { Mission } \\
2007\end{array}$ & $\begin{array}{c}9-17 \\
\text { August } \\
2007\end{array}$ & $\begin{array}{l}\text { Urumqi, Autonomous } \\
\text { Region Xinjiang, China; } \\
\text { Chelyabinsk Oblast, } \\
\text { Military District Volga- } \\
\text { Ural, Russia }\end{array}$ & $\begin{array}{l}\text { China, Russia, } \\
\text { Kazakhstan, } \\
\text { Kyrgyzstan, } \\
\text { Tajikistan, } \\
\text { Uzbekistan }\end{array}$ & $\begin{array}{c}6500 \\
\text { soldiers }\end{array}$ \\
\hline $\begin{array}{l}\text { Peace } \\
\text { Mission } \\
2009\end{array}$ & $\begin{array}{c}22-26 \text { July } \\
2009\end{array}$ & $\begin{array}{l}\text { Taonan, Jilin province, } \\
\text { China; Khabarovsk, } \\
\text { Khabarovsk Krai, } \\
\text { Russia }\end{array}$ & China, Russia & $\begin{array}{c}2600 \\
\text { soldiers }\end{array}$ \\
\hline
\end{tabular}

It was a demonstration of political and military will to continue cooperation to create good conditions for the development of both countries and all the SCO member states. This may also explain the less ambitious nature of the 2009 exercises.

The exercises program is a message demonstrating to the SCO members from Central Asia that Russia and China are reliable partners. ${ }^{38}$ It was visible especially as Russian and Chinese troops and personnel carried the main combat tasks during "Peace Mission" exercises. So, it was presented that they are capable to be involved in direct combat as main players, supported by troops from each other's contingents. As an effect of joint exercises and close cooperation the SCO is strengthening its antiterrorist capabilities and readiness to deal effectively with the new challenges facing the Central Asia with Russia and China as leading nations. ${ }^{39}$ Finally, traditional SCO cooperation over security issues has now gone beyond "the original issues of regional disarmament and border security and delimitation to include practical cooperation in dealing with non-traditional threats." ${ }^{40}$ Military cooperation is supporting economical goals connected with Chinese interests related to Central Asia, as containing asymmetrical

37 Source: Ministry of Defence, Russia, www.mil.ru/eng/, SOW Website www.sectsco.org; Yan Wei, "Partnership in Security," Beijing Review (2 August 2007), www.bjreview.com.cn/ world/txt/2007-08/02/content_71251_2.htm; de Haas, “The "Peace Mission 2007" Exercises," 12.

38 Roger N. McDermott, The Rising Dragon: SCO Peace Mission 2007, Occasional Paper (Washington, DC: Jamestown Foundation, October 2007), 3; available at www.jamestown.org/uploads/media/Jamestown-McDermottRisingDragon.pdf.

Ibid., 3 .

40 Ibid., 12. 
threats and supporting local governments is securing the flow of resources via those countries in the long term. So, it is rather obvious that China's economic growth requires stable environment which is secure and peaceful in relation to the Central Asia and in the global dimension. By providing safe and secure environment China is also securing current leadership in the region which is working with the country very closely and is providing preconditions to build a bridge with the Middle East.

It is significant that this process is triggering a sort of "muscular" economic integration centered on the activities of the SCO. The parallels with the EU are also clear, as China and Russia are adopting the roles of senior partners within the Organization, the way France and Germany perform the same function in the EU. Although similarities should not be overblown into general trends, the tendencies are worth watching.

\section{Parallel Land Lines of Supplies}

In addition to shaping regional security China is also tightening economic relations and is improving constantly the pipeline networks from Central Asia as next to diversification she is looking for security of supplies. As China has limited natural resources, in the nearest future it will still rely on imported oil, for example "China's import of Middle East oil now constitutes 58 per cent of [total imports] and is expected to increase to 70 per cent by 2015." ${ }^{41}$ This is why sea lines of communications are so important, especially the Straits of Malacca as "security and access to sea lines of communication (SLOCs) is of increasing importance, as these sea lines are the maritime highways for vast trade flows critical to the rapidly growing prosperity not only of the Northeast Asia region, but also for the entire Asia-Pacific." ${ }^{42}$

Such an importance at the same time reveals an important weakness, which can be exploited by any third party, influencing the Chinese economy by stopping or restricting flow of raw materials. Moreover, the Chinese PLA Navy is still rather littoral water-oriented, and long-term projects are on the way to create "blue water" capabilities, including force projection. Nevertheless, ongoing aircraft carrier projects and research in the field are time and resource consuming developments so in the nearest future SLOCs will remain fragile. This is why land suppliers and land pipelines are as important to China, as any actor that has the capability to control maritime chokepoints can create potential troubles influencing not only the economy but also the political and social situation in China.

41 Mokhzani Zubir and Mohd Nizam Basiron, "The Straits of Malacca: The Rise of China, America's Intentions and the Dilemma of the Littoral States," Maritime Institute of Malaysia online articles (April 2005), 3; available at www.southchinasea.org/docs/Zubir\%20and\%20 Basiron,\%20Malacca,\%20America,\%20and\%20China-MIMA\%20Online.pdf.

42 Stanley B. Weeks, "Sea Lines of Communication (SLOC) Security and Access," IGCC Policy Paper (Institute on Global Conflict and Cooperation, University of California, February 1998); available at https://www.ciaonet.org/wps/stm02/pp33-5.html. 
FALL 2010

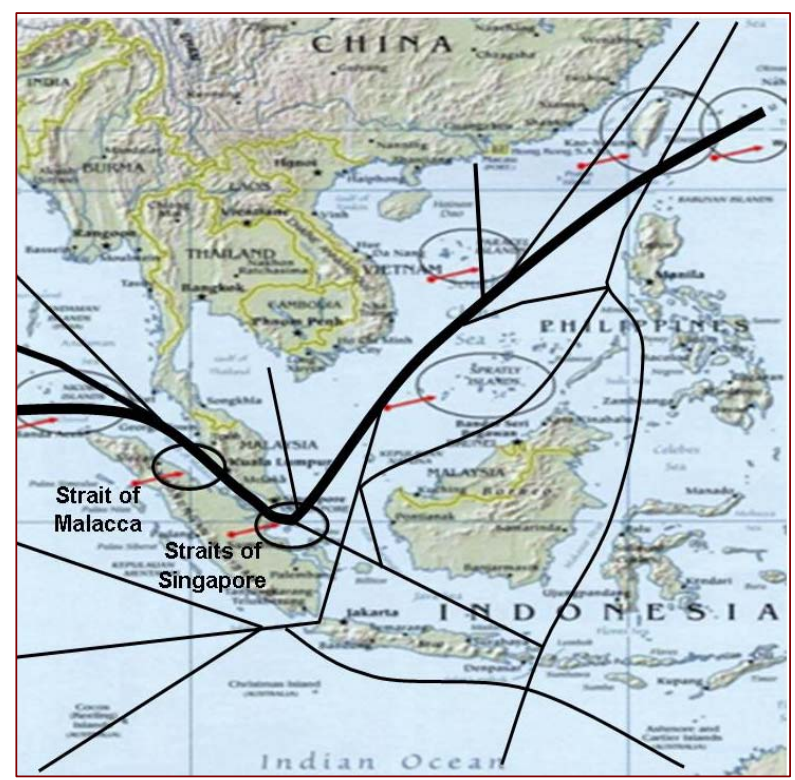

Figure 2: Sea Lines of Communication in the South-East Asia. ${ }^{43}$

No doubts the Straits of Malacca and Singapore are the real chokepoints of SLOCs connecting the Indian and Pacific Oceans. ${ }^{44}$ The Strait of Malacca regarding the flow of oil is smaller only when compared to the Strait of Ormuz, having 50000 big trade ships yearly crossing the waters, including 40-50 tankers per day ${ }^{45}$ providing total $80 \%$ of oil to China, Japan and South Korea. At present the threat is connected only with piracy there and in the South China Sea. However, as a result of The Association of Southeast Asian Nations (ASEAN) actions in the area the threat is no longer significant one. In 2004 ASEAN started operation "MALSINDO" with 17 warships from Indonesia, Malaysia and Singapore; next in 2008 Thailand also joined it. The operation turned into the Malacca Strait Patrols (MSP) ${ }^{46}$ which included three essential elements: the Malacca Strait Sea Patrols (MSSP), the "Eyes-in-the-Sky" Air Element (September 2005) and an Intelligence Exchange Group (2006). Such multidimensional and international approach along with regulations provided a quick reduction of piracy. Moreover, it was supported by other countries out of the area, including the US-lead

43 Based on: Weeks, "Sea Lines of Communication (SLOC) Security and Access," Figure 1.

44 Piotr Kwiatkiewicz, "Cieśniny - Naftowe wąskie gardła," Gigawat Energia 1 (Krakow, 2007); available at http://gigawat.info/archiwum/article/articleview/922/1/72.

45 Robert Czulda, "Nowe wyzwania i zagrożenia na obszarach morskich," Przegląd Morski (Warsaw, January 2009), 41.

46 Joshua Ho, "Cooperative Mechanisms in the Malacca Straits," paper presented at the International Maritime Security Conference (Singapore, 14 May 2009). 


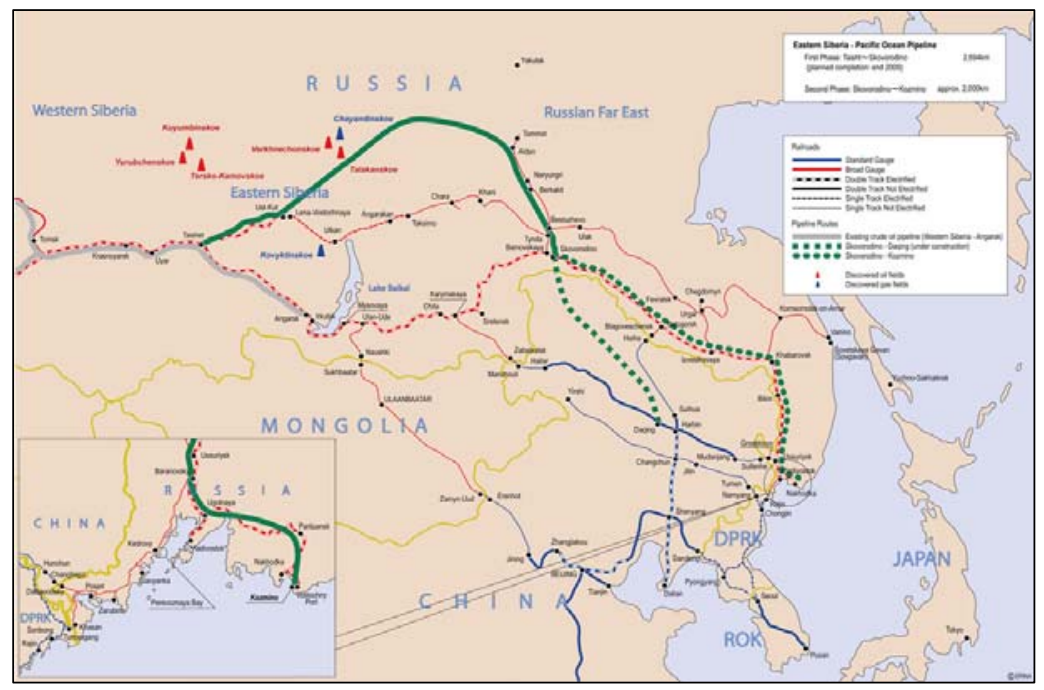

Figure 3: Eastern Siberia - Pacific Ocean Oil Pipeline (ESPO oil pipeline). ${ }^{47}$

Regional Maritime Security Initiative (RMSI) and Five Powers Defense Arrangement (FPDA) with Malaysia, Singapore, Australia, New Zealand and United Kingdom. ${ }^{48}$ ASEAN's legitimacy in the eyes of the US and the Five Powers represents a factor of containment of piracy, but also demonstrates Western economic interests in the region. To a certain extent, these interests are mutual with those of China, but when the issue of Taiwan and the Spratley Islands is added to the mix, there are also factors of significant competition.

Having in mind the fragility of SLOCs and the force-in-being from ASEAN and other powers, it is easier to understand the importance China is putting on continuity of cooperation with Central Asia and on creating new and capable pipelines. Cooperation with Russia resulted, among many other initiatives, also with a concept to build the spur of the Eastern Siberia-Pacific Ocean oil pipeline (ESPO oil pipeline) ${ }^{49}$ which will consists of a 64 kilometer-long section from Skovorodino to the Amur River on the Russia-China border, followed by a 992 kilometer-long section from the border to Chinese refinery in Daqing. A contract is totaling some 30 billion USD. The pipeline will be built and operated by Russian Transneft in cooperation with the CNPC, as China will support the project with money. It is expected that Chinese spur of the ESPO will be finished by October 2010. When opening the first part of the pipeline on 28 De-

47 Source: www.erina.or.jp/en/Asia/map/index5.htm.

48 Yun Yun Teo, "Target Malacca Straits: Maritime Terrorism in Southeast Asia," Studies in Conflict \& Terrorism 30:6 (June 2007): 541-562.

49 “ESPO Pipeline, Siberia, Russia," Hydrocarbons Technology, http://www.hydrocarbonstechnology.com/projects/espopipeline/. 
cember 2009 Prime Minister Vladimir Putin said that "it is an important event for Russia. It is a strategic project, which enables us to enter new markets in the Asia-Pacific region" as Russia's presence in the region's markets was "insufficient." ${ }^{50}$ Again, this leaning towards the East corresponds to the political containment that Russia is enduring in the West.

The Kazakhstan-China Crude Oil Pipeline joint project of CNPC and KazMunaiGaz became operational in 2005; as a result Kazakhstan is providing oil to Xinjiang province with a capacity of 120000 bpd. Full capacity will be reached in 2011. Another joint pipeline is the Kenkiyak-Atyrau Pipeline being the first oil pipeline built in Kazakhstan since independence. CNPC has been cooperating with Kazakhstan companies from 1997, and "operates five oilfield development projects (CNPC AktobeMunaiGas, North Buzachi, PK, KAM and ADM), two exploration projects, the Kazakhstan-China Crude Oil Pipeline and the Northwest Crude Pipeline." ${ }^{51}$ It is important to notice that CNPC owns two thirds of the PetroKazakhst. Hence, this cooperation is also important for Kazakhstan as it is decreasing reliance on Russia, and there is a direct link between provider and a reliable long-term customer.

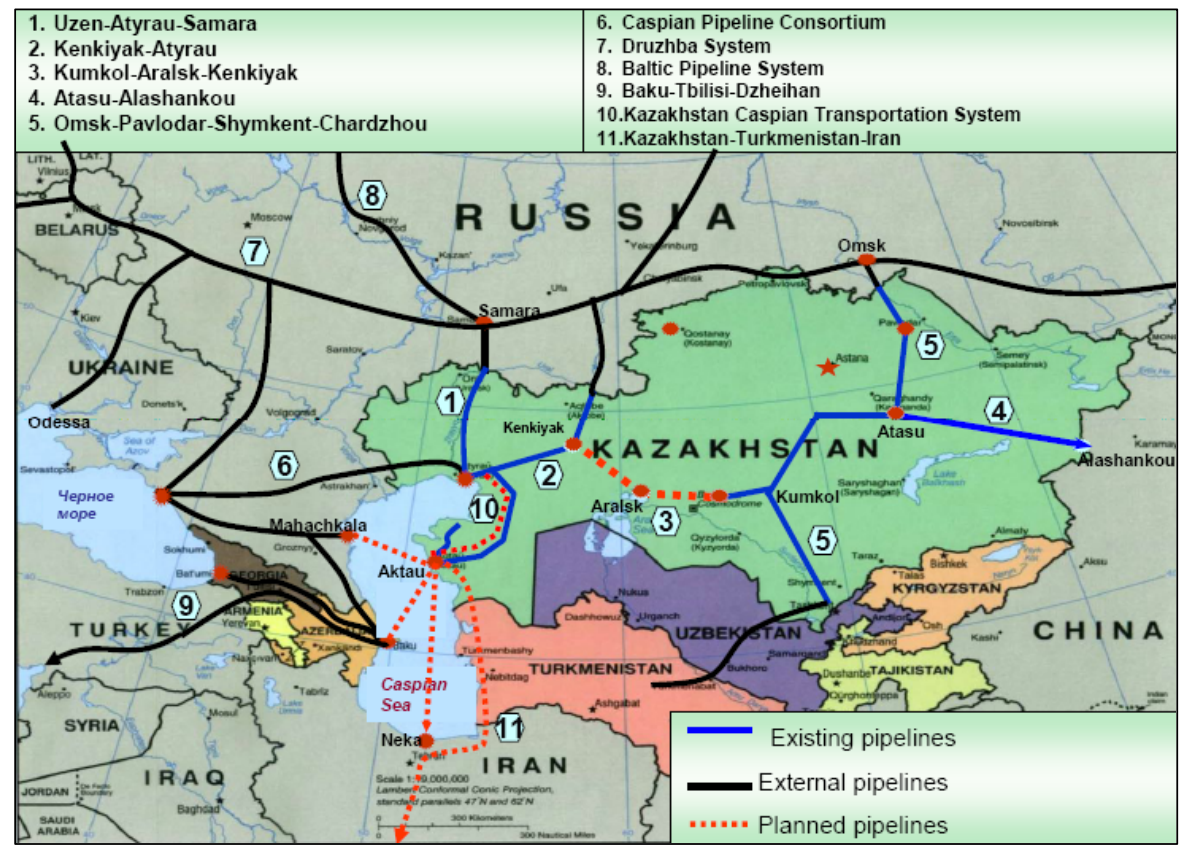

Figure 4: Oil Transportation Routes in Kazakhstan. ${ }^{52}$

50 "Putin says Pacific oil pipeline 'strategic project,"” RIA Novosti (28 December 2009); available at http://en.rian.ru/russia/20091228/157396560.html.

51 Compare: China National Petroleum Corporation Website, http:/www.cnpc.com.cn/eng/ cnpcworldwide/euro-asia/Kazakhstan.

52 Source: Saurbek, "Kazakh-Chinese Energy Relations," 83. 
Gas supplies are also improving, especially with the new project called Turkmenistan-China gas pipeline which will link four nations directly. On 14 December 2009 it was officially opened by Chinese President $\mathrm{Hu}$ Jintao along with counterparts from Turkmenistan, Kazakhstan and Uzbekistan, but the whole project will be completed in $2011 .^{53}$ The 1,833 kilometers-long project will enable the transit of 40 billion cubic meters of natural gas per year (30 billion from Turkmenistan and 10 from Kazakhstan). Running from Turkmenistan, it is crossing central Uzbekistan and southern Kazakhstan and finishing in the northwest region of Xinjiang. Inside China it is distributing energy to major cities including Shanghai, Guangzhou and Hong Kong.

In general, the land connections are still improving in length and capacities, especially as a result of China's proactive approach and close relations between her foreign policy and energy security. Although land pipelines will not fully replace reliance on SLOCs, they are bringing more flexibility. At the same time Chinese influence on global energy policy will increase as she will influence not only producers of oil and gas but will partially control distribution as well which, as the Russian example proved, can be an important tool to affect the economies of many countries.

\section{Conclusions}

China has a long-term vision on how to secure uninterrupted energy supplies into the country. The policy underlines several such factors. First, next to securing provisions from "old" providers the country is looking extensively for new credible sources. Second, she is trying to shape the security environment in areas of interest to get local support and preconditions to continue cooperation. Finally, China is fully aware of the fragility of sea lines of communications, so it tries in parallel to secure land pipelines via friendly countries as an alternative in case of disturbances. In this case a very important role is played by nationally controlled oil and gas oriented companies like CNPC, which are investing money and are also co-owners. Such a situation is really important to influence the flow of goods in the long term. CNPC is following the priorities of foreign policy focusing on energy security for the country as is present in many countries. Such good effectiveness of Chinese companies could create in the future a land-based "Pan-Asian Global Energy Bridge" connecting providers of oil and gas (The Middle East, the Central Asia, and Russia) with Asian customers (China, Japan, South Korea). China could acquire a strategic position regarding distribution of such energy supplies. ${ }^{54}$ Moreover, it could influence the building of pipelines to the West by signing contracts with strategic providers.

At the same time, it is necessary to point out that China's energy reliance on only one country - Russia, could be used as a tool of political pressure by the latter. Such a situation is making relations between countries rather special as next to economic concerns they have the same multilateral vision of the world order. Relations among en-

53 "Chinese, Turkmen, Kazakh, Uzbek Presidents Unveil Gas Pipeline," SCO Website (14 December 2009); available at www.sectsco.org/EN/show.asp?id=168.

54 Ögütçü, "Kazakhstan’s Expanding Cross-Border Gas Links,” 15. 
ergy reserves, influences, control of pipelines and funds to invest make the situation more complicated but with perspectives to continue cooperation in all dimensions. One more issue is rather important for China, and it is direct land connection with Siberian reserves, which is again decreasing the dependence on SLOCs. The energy cooperation with new partners is beneficial for all the participants in the exchange. For the Central Asian countries it is an important chance to reduce reliance on Russian distribution system and to get a long-standing partner and is creating the background to enhance regional economic cooperation into other areas. In other words, and much like the EU, the principle of interdependence is shaping the East's economic and security environment. Such cooperation is also connected with military sector, as during exercises countries are exchanging experiences and they are building mutual trust. Here again, the EU's example seems to be mirrored. At the same time, it can be followed by weapon sales by China to partners in the region, which would be again an important factor of such partnership. However, inside the SCO there are two important and capable weapon and equipment exporters who are trying to win the competition in this lucrative business. But even here, the situation is not unlike the EU, where NATO members are also producers of military equipment.

China is also putting the accent on the better use of energy resources inside the country by implementing new technologies aiming to reduce oil consumption. However, some of them are expensive to implement. Another possibility is to make better use of own resources by their more efficient exploitation, e.g. in the Tarim Basin, but again technological capabilities are slowing extraction. Moreover, continuous extension of pipelines would be necessary. At the same time cost-effect calculations reveal that some of the oil fields are inefficiently exploited. Additionally, the importance of Xinjang province for China is very visible when considering energy security, because of the Tarim Basin and also as a direct land link to Central Asia and in the future to the Middle East. This is why the country is cooperating closely with the region to contain the three devils of "terrorism, extremism and separatism," as they are common crossborder threats for all actors.

China will never be fully independent regarding energy resources but current foreign policy is improving the present situation. This is why any disruption in oil supply will have a significant impact on China's economic growth and will be a threat to China. According to the CIA Factbook, the pipelines net is developing rather quickly in China linking the country with Central Asia and providing an opportunity to extend such line to Iran and the whole Middle East. The total length of pipelines as of 2009 is as follow: gas pipelines $32,545 \mathrm{~km}$; oil pipelines $20,097 \mathrm{~km}$ and refined products pipelines $10,915 \mathrm{~km}(2009) .{ }^{55}$ It is quite possible that in the nearest future SCO will create its Energy Club which will be beneficial for China by securing flow of raw materials with the potential to extending economic links to the Middle East. Recently, Chinese President Hu Jintao suggested member states to "enhance cooperation... to oppose the

55 CIA The World Factbook, China, https:/www.cia.gov/library/publications/the-world-factbook/ index.html. 
crisis and consolidate the organization." ${ }^{, 6}$ To support his words, he decided that China granted a $\$ 10$ billion loan to members of the SCO to help them through the economic crisis and by providing more possibilities to run joint economic projects.

In this way, China takes the responsibility of regional leadership seriously. This development is more than a response to Russia's resurgence, however. When we consider the degree of Sino-Russian political, military and economic cooperation, their mutual interests in the energy trade, their security concerns in the "three evils," the commonality of approaches between the political leadership are such that an SCO-led integration seems almost natural.

The worrisome part is that the region is still so insecure. Because of this, a sound strategy must include the protection of avenues of supply both on land and at sea. This triggers the development of regional military capabilities and cooperation that may be seen adversely as a challenge from outside that region. As China's position suggests, a credible military presence to preserve the flow of natural resources to continue growing (and thereby to avoid internal troubles) is also natural. The fact that this posture has been increased in cooperation with Russia is a telling sign that maybe a new block is forming.

Sino-Russian cooperation could leverage the SCO to produce a powerful response to two types of containment. The first type finds its source in the Cold War and concerns Russia. It is connected with the enlargement of NATO which Russia sees as affecting its interest, but which it is powerless (unless her actions in Georgia are counted) to stop. One of Russia's options to alleviate the pressures of this containment is to turn to the like-minded East, and it seems she is doing so. The other type of containment is applied to China by the apparent competition for the control of SLOCs and through the conditionality of trade and most-favoured nation status with improvements in her human rights record and environmental protection efforts. These two sets of pressures drive Russia and China into each other's arms, bringing Central Asia in with them.

We may be seeing the dawn of a new trading block, self-sufficient, and unhindered by considerations of human rights and sustainable and environmentally-friendly development. That in itself is not a source of risk, but the way in which conflict is managed in that region of the world does not accord with the values and norms of the other important trading block, the EU and its Euro-Atlantic partners. Far from an ideological confrontation, we could nevertheless see in the medium term the emergence of trading blocks opposed to each other by the diversity in their norms. One motivated by its attachment to humanistic values, and the other ready to use all necessary means to preserve its right to grow economically.

If the Euro-Atlantic partners are serious about the welfare and the promotion of their values in other regions of the world, perhaps its members would do well not to appear too uncompromising in matters of democracy versus prosperity, lest it precipitate the formation of a military and politically-capable block animated by opposing

56 "China to Grant $\$ 10$ bln Loan to SCO States to Overcome Crisis," RIA Novosti (Yekaterinburg, 16 June 2009); available at http://en.rian.ru/world/20090616/155263957.html. 
values. There is no indication that the formation of a super-trading block is in China's intentions (or even in Russia's), past the manifestation of intra-regional trading and security development. But this process may be taking part in spite of China's intentions. Russia's relative weakness to China (in terms of demographics, just to give one indicator) will necessarily propel the latter into a leadership role, and this function could accidentally land on her shoulders. Once that is realized, the West would feel compelled to treat China as a superpower, and she would then cease to remain a regional power. Whether the West, China and Russia are aware of this process-let alone ready for its implications - is unclear. 


\section{Bibliography}

Barry, M.J. China Will Not Be a Superpower In Course New Horizons Paper. Toronto: Canadian Forces Command and Staff College, 2006.

Bhadrakumar, M.K.. "Shanghai Cooperation Organization Primed and Ready to Fire: Toward a Regional and Global Realignment?" Japan Focus (2007).

C. Bergsten, Fred, Bates Gill, Nicholas R. Lardy, and Derek Mitchell. China: The Balance Sheet: What the World Needs to Know About the Emerging Superpower. New York : Public Affairs, Center for Strategic and International Studies and Institute for Internationa Economics, 2007.

China GDP grows by 8.7 percent in 2009. Beijing: CNN China, 2010.

China to Grant $\$ 10$ bln Loan to SCO States to Overcome Crisis. Yekaterinburg: RIA Novosti, 2009.

China, Russia to Launch Military Drill. China Daily (2005).

Chinese, Turkmen, Kazakh, Uzbek Presidents Unveil Gas Pipeline. SCO Website, 2009.

Continuation of the National Emergency with Respect to Iran In Presidential Documents., 2009.

Czulda, Robert. "Nowe wyzwania i zagrożenia na obszarach morskich." Przegląd Morski (2009): 41.

de Haas, Marcel. The "Peace Mission 2007" Exercises: The Shanghai Cooperation Organization Advances In Central Asian Series 07/28. Shrivenham: Advanced Research and Assessment Group, UK Defence Academy, 2007.

gütçü, Mehmet Ö.. Kazakhstan's Expanding Cross-Border Gas Links. Implications for Europe, Russia, China and Other CIS Countries. Dundee, UK: The Centre for Energy, Petroleum and Mineral Law and Policy at the University of Dundee, 2008.

Ho, Joshua. "Cooperative Mechanisms in the Malacca Straits." In International Maritime Security Conference. Singapore: International Maritime Security Conference, 2009.

How the Andijan Killings Unfolded. BBC News, 2005.

Hu's Visit to C. Asia, Russia Fruitful. China Daily (2007).

Hurst, Cindy. China's Global Quest for Energy. Washington: The Institute for the Analysis of Global Security, 2007.

Iraq Seals Oil Deal with BP, CNPC. China Daily (2009).

Jintao, Hu. Obama agrees to build positive Sino-US ties. Beijing: CCTV, 2009.

Kwiatkiewicz, Piotr. "Cieśniny - Naftowe wąskie gardła." Gigawat Energia 1 (2007). 
Litovkin, Viktor. "Chinese Army Trains on Russian Territory." Nezavisimoe Voennoe Obozrenie 25 (2007): 3.

Major PLA-Related Joint Anti-Terror Military Trainings. News Agency Xinhua, PLA Daily, 2007.

Marat, Erica. Fissures in the Force - Multilateral Cooperation Can Only Go So Far. Jane's Intelligence Review, 2007.

McDermott, Roger N.. The Rising Dragon: SCO Peace Mission 2007 In Occasional Paper. Washington, DC: Jamestown Foundation, 2007.

Morrison, Wayne M.. China's Economic Conditions. Washington, DC: Congressional Research Service, 2009.

Paramanov, Vladimir, and Alexey Strokov. Economic Involvement of Russia and China in Central Asia. Swindon: Conflict Studies Research Centre, Defense Academy of UK, 2007.

Putin Pushes SCO Countries to Form Energy Forum. RIA Novosti, 2010.

Putin says Pacific oil pipeline 'strategic project'. RIA Novosti, 2009.

Saurbek, Zhanibek. "Kazakh-Chinese Energy Relations: Economic Pragmatism or Political Cooperation?" The China and Eurasia Forum Quarterly 6, no. 1 (2008): 93.

Shangwu, Sun, and Wu Zhiyi. "First Joint Drill with Russia Launched." China Daily (2005).

Teo, Yun Yun. "Target Malacca Straits: Maritime Terrorism in Southeast Asia." Studies in Conflict \& Terrorism 30, no. 6 (2007): 541-562.

Three Evils: Terrorism, Separatism and Extremism In Convention on Combating Terrorism, Separatism and Extremism. Shanghai: SCO Website, SCO Joint Statement, 2001.

Tian, Le. "Joint Drill Enters the Final Phase." China Daily (2007): 2.

Vasava, Jayesh. China Frees Turkmenistan from the Diktats of Gazprom. The Article Alley, 2010.

Weeks, Stanley B.. Sea Lines of Communication (SLOC) Security and Access In IGCC Policy Paper. Institute on Global Conflict and Cooperation, University of California, 1998.

Wei, Yan. Partnership in Security. Beijing Review, 2007.

Yadav, Surya N.. India, China and Africa. New Partnership in Energy Security. New Delhi: Jnanada Prakashan (P\&D), 2008.

Yongli, Liang, and Du Xianzhou. "Coalition-2003: A Successful Joint Anti-terrorism Maneuver." PLA Daily (2003). 


\section{THE QUARTERLY JOURNAL}

Zubir, Mokhzani, and Mohd Nizam Basiron. The Straits of Malacca: The Rise of China, America's Intentions and the Dilemma of the Littoral States. Maritime Institute of Malaysia online articles, 2005. 